\title{
Introduction: The Short Story as the Genre of Cultural Transition
}

\section{LYUDMILA PARTS}

During the final decades of the twentieth century short-story criticism went from having to justify its existence as a field of study to being recognized as a prominent area of literary inquiry with its own critical canon. This collection contains some of the most illuminating critical articles treating the short stories that best represent the genre in twentieth-century Russian literature. This introduction focuses on two issues central to the subject at hand: it highlights the main points in short-story criticism and applies them to the Russian short story in particular. However, a definition of the short story is not my aim; rather, I will use others' attempts to define the genre to explore its cultural and sociological function in the Russian context. Is there a specifically Russian short story? And even more to the point, is there something about the twentieth-century cultural and political development that accounts for the short story's prominence in it?

\section{THE SHORT STORY GENRE}

A definition of the genre is in order, even if only an elementary one: the short story is a "brief fictional prose narrative" that "usually presents a single significant episode or scene involving a limited number of characters. [...]" Numerous textbooks rely on just that kind of basic formula. Since the short story is very classroom-friendly, a great number of short story collections perform the honorable function of initiating students into the study of literature. These collections open with the building blocks of short-story theory to provide a background for the study of literary texts in general.

A critical inquiry into the short story as a genre takes the basic formula and explicates, develops, or challenges its elements by examining the centrality of brevity, of an episode-focused narrative structure, and of the "limits" upon the number of fictional actors to the definition of this genre.

These are only some of the issues engendering critical debate and enriching our understanding of how a brief narrative attains its power. 
Most studies address in some way Edgar Allan Poe's review of Nathaniel Hawthorne's Twice-Told Tales (1842), in which Poe advances what has since become a classical definition of the short story. Poe postulates unity of effect as the feature that makes short fiction a unique and superior art form. This "unity of effect or impression" depends on the work's length: if it cannot be "perused in one sitting" (as novels cannot), "it deprives itself [...] of the immense force derivable from totality." A successful tale, therefore, is characterized by a clearly-defined movement toward a preestablished effect, with every word or detail contributing to it. Poe positions the tale above the poem and the novel as the only art form capable of sustaining this unity, of controlling "the soul of the reader" in order to produce an effect that is more lasting than that of a brief poem, and less in danger of being counteracted, if not annulled, by the breaks in reading a novel. Poe here mentions the novel only to dismiss it; he positions the tale as equal to the lyric poem as the only other "class of composition [capable of fulfilling] the demands of high genius."

Poe's brief comment prefigures a major trend in short-story criticism: the tendency to discuss the short story in relation and in comparison to other art forms, especially to the novel. The issue in such comparison is invariably whether the difference is one of degree or kind, or, in other words, whether a short story is like a tiny novel, limited in scope and size but not in its relationship to the same material, or whether the short story deals with different material altogether, focuses on subjects that the novel is incapable of addressing, and has a structure that would not work in a novel. Arguing for a difference of degree seems to relegate the short story to the lesser position of a counter genre, merely a step on the writer's path to the "proper" genre of the novel. Mary Louise Pratt examines the link between the novel and the short story in exactly these terms and discusses eight aspects of this unequal relationship. The first four address the incompleteness of the short story in comparison to the novel: 1) the novel tells a life, the short story tells a fragment of a life; 2) the short story deals with a single thing, the novel with many things; 3) the short story is a sample, the novel is "the whole hog"; 4) the novel is a whole text, the short story is not. The other four address thematic and structural features of the short story: 5) its new and often stigmatized subject matter; 6) its inherent orality, that is, its tendency to incorporate oral-colloquial speech forms; 7) its roots in the narrative tradition of folklore and anecdote, whereas the novel originates in history and document; and finally 8) its status as a craft that can be learned and 
mass-produced. ${ }^{4}$ Pratt's fine analysis, based on the assumption of inequality, identifies those features of the short story that, when taken on their own terms, account for its recognition as a distinct art form.

My preference lies with the critics who undertake the analysis of the short story as an independent genre defined by a set of distinct features an analysis, in other words, neither anchored in nor impeded by another genre's prestige. These critics see the short story as a genre that precedes the novel in time and essentially differs from it in terms of subject, theme, and structure. The most influential and most anthologized observation on the subject matter unique to the short story is by the writer Frank O'Connor. He comments on the nature of short-story heroes:

...the short story has never had a hero. What it has instead is a submerged population group - a bad phrase which I have had to use for want of a better. That submerged population changes its character from writer to writer, from generation to generation. It may be Gogol's officials, Turgenev's serfs, Maupassant's prostitutes, Chekhov's doctors and teachers, Sherwood Anderson's provincials, always dreaming of escape $[\ldots]$. Always in the short story there is this sense of outlawed figures wandering about the fringes of society, superimposed sometimes on symbolic figures whom they caricature and echo - Christ, Socrates, Moses. ${ }^{5}$

Out of this predisposition toward a special kind of hero comes the worldview embodied by the short story, a worldview that is not exactly hostile to but is somewhat dissociated from the view of society as a civilized community embodied by the novel. As a result, "the short story remains by its nature remote from the community - romantic, individualistic, and intransigent." Societies interested in their submerged population, communities whose outlook toward themselves sustains a certain degree of reflection and cynicism, produce better short stories.

Charles E. May, the editor of two influential collections of short-story theory, defines the short story by the kind of experience it reflects: "short fiction, by its very length, demands both a subject matter and a set of artistic conventions that derive from and establish the primacy of 'an experience' directly and emotionally created and encountered." Like O'Connor, May sees a functional link between the subject matter of the short story and the 
attitude toward everyday reality the short story expresses. The experience reflected in the short story is fragmented, emotional, mythic, and asocial. The kind of knowing embedded in the short story is at odds with a view of reality as well-ordered and secure. It defamiliarizes the everyday and "throws into doubt that our propositional and categorical mode of perceiving can be applied to human beings as well as objects."

Just as the subject matter of the short story is specific to the genre, so are its formal features. The structure of the short story is defined by its brevity: because there are so few details, each one receives additional emphasis. In a short story there can be nothing accidental, nothing that does not contribute to the unity of its effect. This is not to say that the short story must have a neat plot structure that guides the reader through the narration of a single event in the character's life. Most modern short stories abbreviate or distort the traditional plot sequence of exposition, development, culmination, and denouement. This manipulation of the plot in order to foreground the style results in what Susan Ferguson calls elliptical and metaphorical plots. Elliptical plots simply delete some of the expected sequential elements, while metaphorical plots substitute seemingly unrelated events for the ones omitted. The result in both cases is that the reader is invited to infer the missing elements. ${ }^{9}$ The most important omission in the modern short story is of the kind of ending that resolves and explains, leaving this task, once again, to the reader. Just like a lyric poem, and much more than a novel, the short story depends for its effect on the ending. Susan Lohafer suggests that the effect of brevity on the short-story reader is to make him or her "the most 'end-conscious' of the readers." 10

The kind of ending offered by the short story depends more on its subject and theme than on its style: its disenfranchised hero and its limited mode of knowing manifest themselves in the tendency toward endings that refuse to bracket the world with neatly-defined beginnings and ends. Most modern stories are either open-ended or offer an ending that seems unsatisfactory, neither resolving the character's problem nor affirming the reader's sense of logic and order. If the short story describes an experience, a moment of truth rather than the moment of truth, as Nadine Gordimer puts it, then the ending can only offer a glimpse into an unfolding experience and cannot presume to sum it up. "The short story is a fragmented and restless form," Gordimer continues, "a matter of hit and miss, and it is perhaps for this reason that it suits modern consciousness - which seems best expressed as flashes of fearful insight alternating with near-hypnotic states of indifference."11 
This point is crucial, in my opinion, to understanding the nature of the modern and postmodern short story: in becoming modern, in shedding the traditional formulaic plot of the fable, the anecdote, and the morality tale, the short story answered the demands of a modern consciousness characterized by a sense of epistemological uncertainty, ambiguity, and fragmentariness. In being "of a moment" the short story is always "of a present moment"; it is a form that responds with immediacy to the sensibilities of its time, to political and ideological climates, and to the way we see the world at large. When our hold on reality is no longer taken for granted, when experience itself becomes fragmented, individualized to the point of dissociation, then the modern short story moves to the foreground of the literary process.

Similar observations are often made by scholars of the American twentieth-century short story; as I intend to show, these apply particularly well to the Russian short story. Richard Kastelanetz defines the American short story from the 1920s to the 1960s by the absence of "the definite moral stance." Even "where one can discern a moral statement in these stories its authority seems pragmatic and tenuous." 12 In this inability to provide a moral message and in the sense of futility of the intellectual quest the short story represents the modern intellectual affliction. As a literary form that takes relatively little time to be written and to be read, the short story functions as a vehicle for a swift inquiry into experience, be it a detached examination or an emotional outburst.

Herein lies a major difference between the short story and the novel: the novel, Frank O' Connor insists, is impossible "without the concept of a normal society." ${ }^{\prime 3}$ Alberto Moravia makes the distinction between the novel and the short story on the basis that ideology functions as bone structure. The novel possesses this ideological skeleton and the short story does not: "It is the ideology, however imprecise and contradictory it may be, with all the contradictions that are to be found in life itself (the novelist is not a philosopher, but a witness), that begets the things that make a novel a novel." 14 The short story deals not just with events and characters that are unsuitable - insufficient? - for the novel, but also tends to privilege these events and characters precisely because its sociocultural function differs from that of the novel. The novel enters into a direct relationship with the dominant ideology: it can be supportive of it, hostile to it, or take it for granted; the short story, by contrast, focuses on the individual's moral and emotional experience. The state, society, and ideology enter the short story in the same way good or bad weather, 
health, or luck do: as external and background factors.

The short story's lack of ideological background accounts for its marginal position in the hierarchy of genres, although there are periods in the development of most national literatures when this very deficiency propels the short story to the foreground of the cultural process. Susan Ferguson traces the rise of the English short story through the literary class system in times of "a certain volatility in the class structure." 15 She concludes that

the preeminence of the short story as a modernist genre grew out of the modern, highbrow audience's acceptance of fragmentation as an accurate model of the world, with a concomitant focus on 'being' - as in Wolf's 'moments of being' - rather than the 'becoming' that characterizes the plot of the Romantic or the Victorian novel. The brevity that marked 'minor' to earlier generations became a badge of the short story's superior representational capacity. For a brief period, in English literature, at least, the short story became not just a prestige genre but the genre that could be said to represent the essence of the age, as did drama at the end of the sixteenth century. ${ }^{16}$

Ultimately, the short story's rise in prestige, its transformation into a highbrow art form, occurred at a time when modernist artists positioned themselves as the "aristocracy in the arts," 17 making the modernist short story, with its emphasis on formal and stylistic innovation, an art form for the few.

Before turning to the Russian short story, let me recapitulate several key points. The short story is a distinct genre with its own characteristic subject matter and formal structure. While it shares many of its formal features with other genres, most notably the lyric poem and the novel (all can be relatively brief, have an open ending, and foreground stylistic innovation at the expense of a linear plot), the protagonist of the short story differs from his or her novelistic counterpart, is less a member of society, however defined, than an individuated conscience on a moral and emotional quest. Moreover, the short story (just like the novel) fulfills a socio-cultural function that is unique to its genre; here the differences between the two genres are most clear. The short story rises to prominence during periods 
of cultural and political transition when literary conventions and ideologies lose some or most of their authority. The Russian twentieth-century short story in particular flourished in a century that saw an abundance of such shifts: cultural, ideological, and political.

\section{THE RUSSIAN SHORT STORY}

The history of the Russian short story has yet to be written. Little attempt at a comprehensive analysis of the genre has been made since the groundbreaking work of the Russian Formalists. ${ }^{18}$ In "The Literary Fact," YuriTynianov provides a useful discussion of the concept of a literary work's size as energy. He proposes that the historical life of genres is characterized by a series of dislocations, that is, changes to what have been considered fundamental signs of a genre. As a result, once-secondary features become responsible for keeping the genre recognizable. The most important of such features is size: "Our expectations of a 'large form' are not the same as of a small form: depending on the size of the construction, each detail, each stylistic device has a different function, a different force, and a different load is laid upon it." ${ }^{19}$

Boris Eikhenbaum's 1925 essay “O. Henry and the Theory of the Short Story” opens by positing an unequivocal division - of kind, not of degree - between the novel and the short story and proceeds to suggest that the short story in general is "a fundamental, elementary (which does not mean primitive) form," and that the nineteenth-century American short story in particular is "built on the principle of structural unity with centralization of basic effect and strong accentuation on finale. ${ }^{20}$ In Eikhenbaum's view, this kind of story is not typical for Russian literature. He proposes the sketch or skaz-type stories as most characteristic for his native literature. ${ }^{21}$

Formalists considered the novel a composite complex genre that historically developed out of various combinations of short-form narratives. According to Eikhenbaum, the Russian short story appeared at times to merely "create a transition to the novel which it is customary for us to consider the more elevated or the more worthwhile genre."Viktor Shklovsky comments that the modern novel arose out of collections of what he, like Eikhenbaum, calls novellas, but takes care to emphasize that there is no "causal relationship" between these genres. ${ }^{22}$

The nature of the novel and of the short story, as well as the very terms applied to these narrative structures, has been changing over the last few 
centuries. Throughout this time, one can discern a certain kind of interaction - not causal, but one that nevertheless exhibits a definite pattern. The short story accompanies periods of change in literary paradigm when culture develops in new aesthetic, linguistic, and thematic directions. In this way the short story lays the groundwork for the novel, but not by providing shorter pieces to be assembled in a complex plot. Its role is to work out innovative aesthetic and thematic models that the novel can later take into the cultural mainstream.

The end of the eighteenth century was a period when Russian culture needed a new literary structure to enable the reform of literary language and to reflect newly-popular philosophical trends and changes in social life. The second half of the century saw the proliferation of translations and adaptations of foreign adventure and sentimental novels by the likes of Fedor Emin, Nikolai Emin, and Pavel Lvov. Sentimentalism, with its express privileging of the emotional over the social, brought attention to a new kind of hero: an ordinary person from the lower strata of society. ${ }^{23}$ With the new protagonist and new literary language came a new genre, the sentimental tale, perfected by Karamzin and popular enough to "decidedly push out the novel." ${ }^{24}$ The sentimental tale served as a vehicle for literary language reform as well as a stylistic experiment. ${ }^{25}$ This short form was quick to react to socio-cultural changes and was flexible enough to reflect these changes in both subject matter and style.

In the first third of the nineteenth century, the rise of the short-form narrative also accompanied a major shift in the cultural paradigm: from poetry to prose, from élite circles of readers to a massive and dispersed readership, primarily of literary magazines. The word rasskaz did not become a widely accepted term for the short story until the second half of the century when it supplanted the eighteenth- and early-nineteenthcentury designations such as istoriia, povest', skazka, or anekdot. ${ }^{26}$ Viktor Terras outlines the major types of the short-form prosaic works of the $1820 \mathrm{~s}-50 \mathrm{~s}$ : the romantic tale, regional and dialect tales, the society tale, and, by the 1840 s and 50s, "the story of a superfluous man" and the social tale in the style of the natural school. ${ }^{27}$ We of course recognize in this list the familiar concerns of the nineteenth-century Russian novel. Chronologically, the shift toward the novel during the second half of the nineteenth century followed the flourishing of the short form. Yet these tales were not merely a step on the way to the more highly-valued genre of the novel; rather, they were the source of the aesthetic, stylistic, and thematic energy the novel needed to 
develop over the next thirty years.

In the 1880 s, with major novelists either gone or turning, in the case of Tolstoy, to short-form narratives, ${ }^{28}$ the short story once again fulfilled its role as the genre of cultural transitions. This time, the shift in literary paradigm - the nascent Symbolist movement with its focus on aesthetic experimentation - was accompanied by a strong sense of political crisis. After the political unrest of the 1870s and subsequent popular disillusionment, writers began to react against the utilitarian critics' demands for social engagement. Moving away from the thematic concerns of the Russian novel also meant turning toward a genre that operates through different thematic and stylistic devices. The Russian Symbolist short story, in a manner akin to its European counterpart, "sought to articulate a more personal perception of human experience and to convey the hidden emanations of [peoples'] psyches. ${ }^{29}$ The move from large-scale concepts of nation, history, and social action toward the concepts of individuated conscience, subjectivity, and marginality was at the same time a move from the novel to the short story.

The author who finalized the shift to what we now recognize as the typical concerns of the short story is Anton Chekhov. Just as Pushkin's achievements in prose have been seen to influence the development of the short story throughout the nineteenth century, ${ }^{30}$ in the 1880s and 90s Chekhov's stories gave the genre new form, new direction, and new unprecedented prestige. Chekhov's role in the history of the Russian short story and his continuing relevance for short-story writers around the world make it very tempting to suggest that while we cannot define a specifically Russian short story, we might consider the twentieth-century short story as such, Russian and otherwise, to be following the paths opened by Chekhov.

The well-documented unease provoked in contemporary critics by Chekhov's poetics is an indication of how drastic this shift seemed at the time. Such was the authority of the novel in Russian literary tradition that Chekhov's stories seemed symptomatic not so much of new directions but of the decline, even destruction, of Russian literature. ${ }^{31}$ Most critics found Chekhov's poetics symptomatic of the intelligentsia's social disillusionment and apathy. A 1926 Soviet textbook for adult schools offers a similarly utilitarian explanation by characterizing Chekhov's short stories, and the genre of the short story in general, as exceptionally well-suited to the speed and feel of life in the capitalist epoch: "The age of electricity, express trains, and airplanes created its own literary form." 32

We can only speculate what new directions the novel might have taken 
after the modernist / Chekhovian short story had not its development been forcefully redirected. A typical Soviet novel of the 1930s, a thematically and stylistically formulaic text, displays little of the short story's experimentation and freshness of perception precisely because it pushed aside, so to speak, the artistic discoveries of modernism and reached back toward the nineteenthcentury Russian novel with its broad social themes and realist poetics.

In Soviet literary criticism, the novel was the preferred genre, with the short story on the defensive. That the "social mandate for a red Leo Tolstoy" (in Mikhail Zoshchenko's phrase) continued to dominate is evinced by Mikhail Sholokhov's famous reprimand to the writers who abandoned the large form during World War II and who, in doing so, lowered their literary standards. Speaking at the Second All-Union Congress of Soviet Writers in 1954, Sholokhov casually equates the length of time devoted to creating a text with its quality. ${ }^{33}$ Short stories and poems were the major literary genres of the Second World War, not surprising in wartime conditions when circumstances changed quickly and shortages of time and supplies did not allow for unhurried reflection. ${ }^{34}$ Most of the wartime stories did appear in newspapers, and differed only slightly from the journalism of the war effort. Yet a major Soviet writer's call for a return to large-scale works (krupnye proizvedeniia) at a forum of great impact (the first major assembly of Soviet writers in the twenty years since the First Congress endorsed socialist realism as the dominant esthetic paradigm) underscores the extent to which the short story was perceived as a suspect genre. When the novel is the officially-sanctioned genre, the short story is forced into the position of lesser and alternative one, and is often perceived as aesthetically and ideologically subversive.

These two features - artistic innovation and ideological unruliness - are most often associated with the short story during the times when cultural and political shifts concur and interrelate. The late $1950 \mathrm{~s}$ and $60 \mathrm{~s}$, with their erratic, short-lived bursts of expansion in the thematic and formal possibilities of works of fiction sanctioned by the literary establishment, provided writers with an opportunity to turn away from the monumental novels of Stalin's time and toward a more nuanced engagement with their experience. Works by young writers and new works by older authors appeared in every popular genre. Poetry enjoyed great popularity. Newlycreated literary journals and almanacs served as high-profile venue for the publication of large numbers of short stories and povesti. ${ }^{35}$ But it was not until perestroika and glasnost', in the 1980s, that critical discourse on the 
short story showed signs of reevaluating the genre and coming to appreciate its role in times of major cultural and political change.

In 1987, a critic writing in Novy mir, a leading magazine of new fiction and a major forum for debates about the state and the future of Russian literature, commented on the short story's socio-cultural function: "The short story strives to indicate new centers of meaning, to capture the nature of interrelated social tendencies. Hence its heightened interest in all kinds of junctions (styki): of times, generations, and different layers of society." The short story comes to be seen as a "'demandingly democratic' genre" that helps literature to keep "what architects call the human scale." Another critic sees the "triumph of 'short prose" in the late 1980s as a deconstruction of the Soviet myth. The short form, in this reading, has undermined the grand metanarratives of Soviet ideology and literature and broken them into basic pieces out of which new myths and new literature (presumably new novels as well) will arise. ${ }^{37}$ The focus of most of these discussions remained socio-ideological, but at the time that aspect was inseparable from cultural concerns.

In 2000, Novy mir established a literary prize for the best short story named after the short story writer Yuri Kazakov (1927-1982). In 2007, another magazine of new fiction, Moskva, dedicated its fiftieth-anniversary issue to the short story, "the capricious genre" that the editors deemed bestsuited to represent the history of the magazine and of the last fifty years of the literary process. The novel/short story tension still informs most critical discourse on the genre but with a reversed hierarchy. A critic, commenting on the list of nominees for the 2002 Kazakov prize, dismissed the novel as "a profitable and therefore emasculated genre," and lauded the short story for its "new styles, new kinds of writing, the widening of thematic scope, and syntactic sophistication. ${ }^{\text {"38 }}$ While reviewing a collection of short stories about the Chechen war, another critic also denounced the novel but for a different reason: as a genre inappropriate for the unstable and crisis-ridden times. ${ }^{39}$ Whether for its artistic sophistication or for its thematic adaptability to periods of crisis, the short story now enjoys the status of a major genre; it is recognized as the source of the artistic energy needed to push the literary process forward.

Multiple anthologies have been published since the beginning of perestroika, most notably of women's prose, and collections of short stories have become increasingly popular. In the Russia of the late 1980s, a number of short story anthologies introduced provincial women writers as a subset 
of marginalized authors and fictional actors. ${ }^{40}$ During this time the short story's subject matter - an individuated and marginalized conscience - was its most distinguishing characteristic. Western feminist and queer scholarship has a rich tradition of considering the short story to be the literary form particularly suited to writing by women and other marginalized groups. The short story as "the outlaw form" narrative" ${ }^{42}$ undermines a simple linear narrative of culture and challenges the established cultural constructs of norm and identity.

With the proliferation of online journals and libraries, the short story seems to have become a truly democratic genre. Online publishing has practically eliminated the delay between writing a story and delivering it to the reader. It has also done away with discernment, flooding cyberspace with what has already acquired the title of "unprofessional literature." ${ }^{43}$ The transition to a new medium has triggered another rise in the popularity of the short story; it has also blurred and reformulated genre distinctions between the short story, diary, blog entry, and works of journalism. The formal signifiers of the short story may change yet again but the genre will remain crucial to the literary process as long as Russian culture sees itself as a culture in transition.

\section{THE PRESENT COLLECTION}

The articles in this collection offer analyses of Russian stories that encompass major aesthetic and thematic concerns of the short story genre in the twentieth century. Considering the turbulent historical background, it is remarkable how these authors persisted in preserving the human scale of their texts and in bringing to the fore the "moments of being," the individual search and discovery, often followed by the loss of love, of (meager) personal happiness, and of the means of artistic expression. In choosing these stories I did not look for specific themes, yet it soon became clear that there were recurring motifs that ran through most of them, most notably those of language, childhood, and memory.

The modernist short story's privileging of formal innovation over civic engagement often puts it in explicit conflict with the nineteenth-century realist (and novelistic) tradition. Fiona Bjorling points out how Boris Pasternak's "Childhood of Luvers" diverges form the nineteenth-century "childhood novels" in its composition, its "lack of descriptive exposition, [and] its fragmentary nature." Pasternak chooses a girl for the subject of his 
"childhood narrative" and foregrounds the physical side of female adolescence. Breaking away from tradition leads the author toward a different type of hero and a taboo subject, and so to the genre best suited for such heroes and subjects: the short story. Svetlana Evdokimova's article on the myth of Echo in Chekhov's "The Darling" - a story built on the complex interplay of desire and scorn for a woman - points out Tolstoy's "misreading" and appropriation of the story at the expense of its textual integrity, a misreading that of course says more about Tolstoy's own moralistic inclinations in his final years than about Chekhov's story. The tension between form and content is the subject of Lev Vygotsky's analysis of Ivan Bunin's "Gentle Breath.” This chapter from Vygotsky's influential 1922 study The Psychology of Art is a refreshingly lucid approach to the relationship between material and form in literature - an approach that preserves its relevance today. The artistic form - the arrangement of plot elements and the rhythm of poetic language - overcomes the banality of the material, making it "speak the language of gentle breath.”

Robert Maguire emphasizes the primacy of language to artistic and personal experience in his analysis of ekphrasis in Isaak Babel's "Pan Apolek." The story is concerned with the transformation of visual into verbal experience. The uneasy relationship between the word and the image parallels the narrator's struggle to both articulate and establish his place in life. The importance and the limits of language in such an attempt are also, as Andrew Barratt shows, a major concern in Yuri Olesha's "Liompa." Mikhail Zoshchenko's “The Electrician," a story set in a theater, in which two media - the verbal and the visual - routinely integrate into a single art form, can also be understood, in Alexander Zholkovsky's reading, as a story of a hierarchical clash: lowly electrician vs. tenor, a short story writer vs. classical novelists, and a satirist vs. ideologicallyagreeable realists. In Vasily Shukshin's "Cut Down to Size," the characters' language during their verbal duel reflects their transitional status - the status that marks them as proper short story subjects. Diane Nemec Ignashev points out how language also signals Shukshin's own uneasiness about belonging neither in the village nor in the city. In Viktor Erofeev's "The Parakeet," language is characterized by dissonance and paradox. The seamless conflation of Soviet bureaucratic clichés, "terminology" of torture, and folk poetics, undermines the very concept of a linguistic and social norm, according to Mark Lipovetsky's analysis.

Language as a social and ideological phenomenon is a major theme in 
Andrei Platonov's “The River Potudan.”The hero's regression into an infantile pre-verbal and pre-sexual state is indicative of Platonov's problematical attitude toward writing and sexuality in the world of utopia. The muteness of the hero, Nikita Firsov, marks his escape from the world and signifies the complete disintegration of language in a utopia. "Utopia," Eric Naiman comments, "connotes a 'withering away' not only of the state and of the phallus but of the tongue and pen as well." Daniil Kharms's experiments with language and subject matter have always been perceived as ideologically charged. Robin Miller-Gulland sums up recent studies of "The Old Woman" and argues that Kharms's testing of the limits of textual cohesion relates to the issue of the status and authority of the writer as much as to the themes of faith, free will, and power. Leona Toker's article on Varlam Shalamov's "Condensed Milk" presents it as a story of limits: of human psyche and of language's ability to convey suffering without trivializing it.

The theme of childhood emerges as related to the problem of language through the frequent association of the child's fresh perception of the world with the artist's perception. The nameless "rubber boy" in "Liompa" stands on the brink of understanding the world just as he is learning to name its parts. In "The Childhood of Luvers" too, the concern with childhood "is not the concern with moral innocence but with perceptive and cognitive innocence." Thus "the comparison between adolescent child and poet lies beneath the surface [...] both are struggling to put words and realties together." Here the theme of poetic expression and just expression come together in the image of "artist as child."

The most persistent theme in twentieth-century Russian literature, I suggest, is the theme of memory: artistic, individual, collective, and cultural. In "Spring in Fialta," Vladimir Nabokov makes use of short fiction's power to contain a glimpse of personal truth. As John Burt Foster demonstrates, such moments of emotional intensity are what Nabokov's protagonist attempts to capture and preserve when he engages memory "as the faculty that preserves the heart's commitments in the wake of immediate emotion." As a result the protagonist achieves an "awareness of an art of memory that would link the heart with the imagination by recollecting sharply focused portions of the past." In Catharine Nepomnyashchy's article on Tertz's "Pkhentz," the alien's memory of his home world constitutes the most important part of his identity. As it fades, so does his very being. Viacheslav Pietsukh sees the historical past as a rough draft for literary texts. As Mark Lipovetsky demonstrates in his analysis of "Central-Ermolaevo War," 
Pietsukh's category of "'national character' [is] a form of ironic compromise with literary tradition, the historical past, and the present," all touched by the absurd and all subject to ironic reevaluation.

Just as the collective memory of a people sorts through past events to privilege those that support the current national identity, cultural memory allots the highest value to texts that confirm and advance this self-image. Pushkin's works, as well as his biography, became a major part of cultural memory and an inexhaustible source of intertextual material for later generations of Russian writers and readers. Andrei Bitov, in "Pushkin's Photograph, 1799-2099," not surprisingly bases his account of a failed attempt to know history actively on the impossibility of knowing the real Pushkin. Sven Spieker describes the cultural quest for Pushkin in terms of a psychotic's inability to accept loss. Tatiana Tolstaya's "The Poet and the Muse" juxtaposes a contemporary poet to the ideal poet, Pushkin, and lays bare the mechanisms by which our cultural myths form our vision of a poet and our own historical, cultural and personal experiences. Erika Greber demonstrates how Tolstaya's carnivalized "critique of socio-cultural stereotypes and norms" results in the blurring of genre boundaries, that is, in carnivalization of the short story genre itself.

Lyudmila Petrushevskaya's story "The Lady with the Dogs," whose first English translation, by Krystyna Anna Steiger, is included in this collection, works with the reader's cultural memory as it both signals an intertextual connection with Chekhov's "The Lady with a Dog" and develops the relationship between Chekhov's story and Tolstoy's Anna Karenina. I argue in my article that the result of Petrushevskaya's narrative intrusion into the dialogue between two classics on the nature of love and compassion is a grim pronouncement on the modern world, a requiem for lost or discarded values. Viktor Pelevin's "Nika" also reaches back toward the classics and alludes to both Bunin's "Gentle Breath" and Vygotsky's analysis of the same story. In the process, Olga Bogdanova argues, postmodernist Pelevin "draws a detailed portrait of a contemporary version of the classical hero(es) of Russian literature, modified by time and circumstances, and preserving within itself an inherent dominant idea of a national type."

The protagonists of these stories - children, old people, those who are strangers in their time and place, marginal people with neither full voice nor agency - bring to mind O'Connor's astute observation on the nature of the short story hero. Pelevin's cat protagonist clearly pushes the limits of the short story's unconventional character. The postmodern 
short story still privileges the marginal subject in a world of (self-imposed) epistemological limits, but its playful self-reflexivity actually reinforces the genre's flexibility and vitality.

The short story has been changing along with other genres; its role and status in various cultures differ, making a trans-historical and trans-cultural perspective on the genre problematic. In a Russian context, the story's relationship to social and literary history brings to light its evolving features as well as its consistent function. On the one hand, the short story flourishes when a shift in cultural paradigm requires new aesthetic means, style and subject matter. On the other, when such cultural shifts are accompanied by socio-political changes the genre's energy puts it at odds with both the aesthetics and the ideologies of the mainstream. In Russian literature (and probably in most literatures in which the novel dominates) the short story serves as a corrective structure; it redirects cultural production toward new developments. Artistically, the short story is often complex, even dense, but thematically it is consistently open-minded: while the novel gives us the world as an object of reflection and possibly understanding, the short story turns our attention back to a moment, an emotion, an experience unmediated, and the human being "as is." 


\section{ENDNOTES}

1 Encyclopaedia Britannica, http://www.britannica.com/EBchecked/ topic/541698/short-story

${ }^{2}$ Edgar Allan Poe, "Review of Twice-Told Tales," in The New Short Story Theories, ed. Charles E. May (Athens: Ohio University Press, 1994), 60. Emphasis in the original.

${ }^{3}$ Ibid., 61.

${ }^{4}$ Mary Louise Pratt, "The Short Story: the Long and the Short of It," Poetics: International Review for the Theory of Literature 10: 2-3 (1981 June): 175-194. Also in May, The New Short Story Theories, 91-113.

${ }^{5}$ Frank O’Connor, “The Lonely Voice," in Short Story Theories, ed. Charles E May (Athens: Ohio University Press, 1976), 86-87.

${ }^{6}$ Ibid., 88.

${ }^{7}$ Charles E May, "The Nature of Knowledge in Short Fiction," in May, The New Short Story Theories, 133.

${ }^{8}$ Ibid., 137.

${ }^{9}$ Susan Ferguson, "Defining the Short Story. Impressionism and Form," in May, The New Short Story Theories, 221.

${ }^{10}$ Susan Lohafer, Coming to Terms with Short Story (Baton Rouge: Louisiana State University Press, 1983), 94.

${ }^{11}$ Nadine Gordimer, "The Flash of Fireflies," in May, The New Short Story Theories, 265.

${ }^{12}$ Richard Kastelanetz, "Notes on the American Short Story today," In May, Short Story Theories, 224.

${ }^{13}$ O’Connor, “The Lonely Voice,” 86.

${ }^{14}$ Alberto Moravia, "The Short Story and the Novel," in May, Short Story Theories, 149.

${ }^{15}$ Susan Ferguson, "The Rise of the Short Story in the Hierarchy of Genres," in Short Story. Theory at a Crossroads, ed. Susan Lohafer and Jo Ellyn Clarey (Baton Rouge/London: Louisiana State University Press, 1989), 180.

${ }^{16}$ Ibid., 191

${ }^{17}$ Ibid.

${ }^{18}$ A number of studies address individual short-story writers' contributions to the genre. There are also numerous surveys of the genre during a particular period. One study, The Russian Short Story. A Critical History, ed. Charles A. Moser (Boston: Twayne Publishers, 1986), stands apart as it covers a period of 150 years. It is not a theoretical study but is probably the most comprehensive chronological overview 
of the Russian short story to date. The book is a part of the Twayne's Critical History of the Short Story series, an accessible introduction to major themes and authors.

19 Yuri Tynianov, “The Literary Fact," in Modern Genre Theory, ed. David Duff (Essex: Longman, 2000), 31-32.

${ }^{20}$ Boris Eikhenbaum, "O. Henry and the Theory of the Short Story," trans. I.R. Titunik, in May, The New Short Story Theories, 87.

${ }^{21}$ Usually Eikhenbaum, like most Formalists, differentiates between novella and rasskaz: the novella is an action story with an accentuated ending like the ones he discusses in the O. Henry essay. In this work, however, Eikhenbaum's use of the term novella is much more inclusive. He concludes the essay with a reference to the contemporary (in 1925) American novellas of Theodore Dreiser, Sherwood Anderson, Waldo Frank, and Ben Hecht, which display "a movement toward the novella of manners (nravoopisatel'naia) and psychological analysis, in which the material has a more important formal function than the structure.”

${ }^{22}$ Viktor Shklovsky, "The Structure of Fiction (Struktura rasskaza i romana)," in his Theory of Prose, trans. Benjamin Sher (Elmwood Park, IL: Dalkey Archive Press, 1990), 65.

23 “Ordinary representatives of Russian society - nobility, petty bourgeoisie, merchants, and even peasants - came to replace the heroes of the classical poema and tragedy. The peasants soon came to occupy a central place in sentimental literature. P. A. Orlov, Russkaia sentimental'naia povest' (Moscow: Izdatel'stvo Moskovskogo universiteta, 1979), 26.

${ }^{24}$ Ibid.

25 “The appearance of the genre of the sentimental tale was a manifestation of the same basic distinctive feature of the epoch which also figured in the formation of Karamzin's prose: the need for the reform of the literary language. Genre evidences all the distinctive features of an epoch's main impetus." K. Skipina, "On the Sentimental Tale," in Boris Eikhenbaum and Yuri Tynianov, eds., Russian Prose, trans. and ed. Ray Parrott (Ann Arbor: Ardis, 1985), 34.

${ }^{26}$ See for instance Literaturnaia entsiklopedia: Slovar' literaturnykh terminov, ed. N. Brodksy et al. (Moscow/Leningrad: Izdalet'stvo L. D. Frenkel', 1925).

${ }^{27}$ Viktor Terras, “The Russian Short Story 1830-1850," in The Russian Short Story. A Critical History, ed. Charles A. Moser (Boston: Twayne Publishers, 1986), 1-5.

${ }^{28}$ It is remarkable that Tolstoy turned to the short story genre in search of a vehicle for a simple, if not simplistic, moral tale. Tolstoy's later short stories (such as "Master and Man" and "Alyosha the Pot") are an attempt to force the genre into fulfilling a function alien to it: in attempting to embrace a novel-scale philosophical statement they violate the nature of the short story genre. 
${ }^{29}$ Julian W. Connolly, “The Russian Short Story 1880-1917,” in Moser, The Russian Short Story.

${ }^{30}$ Charles A Moser, "Introduction: Pushkin and the Russian Short Story," in Moser, The Russian Short Story.

${ }^{31}$ On critical reception of Chekhov's poetics see Lyudmila Parts, The Chekhovian Intertext: Dialogue with a Classic (Columbus: The Ohio State University Press, 2008), chapter 3.

32 Ia. A. Nazarenko. Istoriia russkoi literatury XIX veka (Moscow: Gosizdat, 1926), 387.

33 "It is clear that during the war the majority of the writers could not even imagine creating large works (krupnye proizvedeniia) nurtured during hard and lengthy contemplation, written in a well-honed language, and impeccable in style.” M. A. Sholokhov, Sobranie sochinenii v 8-mi tomakh (Moscow: Gosudarstvennoe izdatel'stvo khudozhestvennoi literatury, 1956-1960), vol. 8, 297.

${ }^{34}$ On Soviet war-time story see A. V. Ognev, Russkii sovetskii rasskaz (Moscow: Prosveshchenie, 1978); E. A. Shubin, Sovremennyi russkii rasskaz. Voprosy poetiki zhanra (Leningrad: Nauka, 1974).

35 The twentieth-century povest', a long short story, is usually defined as a genre between the novel and the short story. One of the major writers of the period, Yuri Trifonov, worked in the genre of the short story, the novel, and most successfully, the povest'. His povesti provide an interesting example of the tension between the novelistic impulse to represent on a large scale and the subject's - the private and the quotidian - resistance to the long form. The povest', a long short story, is a compromise of sorts given Trifonov's emphasis on private life.

36 Vladimir Novikov, “Oshchushchenie zhanra. Rol' rasskaza v razvitii sovremennoi prozy," Novy mir 3 (1987): 246.

37 M. Galina, "Literatura nochnogo zreniia. Malaia proza kak razrushitel' mifologicheskoi sistemy," Voprosy Literatury 5 (1997): 4.

${ }^{38}$ Dmitri Bavilsky, “Znaki prepinaniia \#34,” Topos (24/12/02).

39 "The novel is not the hero of our time. It doesn't belong here for a while." Andrei Rudalev, "Nastoiashchii rasskaz (Aleksandr Karasev, Chechenskie rasskazy. Moscow: Literaturnaia Rossiia, 2008),” Zavtra 9: 143 (24/09/2008).

${ }^{40}$ See Benjamin M. Sutcliffe, The Prose of Life. Russian Women Writers from Khrushchev to Putin (Madison: The University of Wisconsin Press, 2009), chapter 3 and conclusion, ff. 2.

${ }^{41}$ Ellen Burton Harrington, "Scribbling Women and the Outlaw Form of the Short Story," Scribbling Women and the Short Story Form. Approaches by American and BritishWomenWriters, ed. Ellen Burton Harrington (New York: Peter Lang, 2008). 
${ }^{42}$ Axel Nissen, "The Queer Short Story," in The Art of Brevity. Excursions in Short Story Fiction Theory and Analysis, ed. Per Winther, Jacob Lothe, and Hans H. Skei (Columbia: University of South Carolina Press, 2004).

${ }^{43}$ N. A. Konradova, "Neprofessional'noe pisatel'stvo v Internete: o transliatsii 'literaturnosti', Russian Regional Reading Council http://www.rusreadorg. ru/issues/hl/hl3-09.htm; “O grafomanii v Seti” Novy mir 8 (2003): 200-206. 